\title{
PENGELOLAAN PENGADAAN BARANG OPERASIONAL RESTORAN SKYLINE DI HOTEL IBIS PADANG
}

\author{
Nur Anisa ${ }^{1}$, Kasmita ${ }^{2}$ \\ Program Studi D4 Manajemen Perhotelan \\ Jurusan Pariwisata \\ FPP Universitas Negeri Padang \\ Email : nuranisa.piliang60@yahoo.com
}

\begin{abstract}
This research is motivated by the poor management of the procurement of skyline restaurant operational goods due to the frequent situation of urgent goods but the user rarely directly engages in receiving goods, is not right in planning procurement of goods, organizational structure is not lived properly, and lack of communication in ordering goods. This research is a descriptive study with a qualitative approach. The sampling technique used was purposive sampling which consisted of purchasing staff and $F \& B$ Manager. Data collection techniques are carried out using interview, observation, and documentation methods. Data analysis techniques are used through three stages, namely: data reduction, data presentation, and conclusion. Based on the results of research conducted, it was found several things related to the management of the procurement of skyline restaurant operational goods, namely: purchase requests, supplier selection, purchase orders, receipt of goods, and recording of purchase transactions whose entire process must pay attention to several management functions including planning, organizing, directing and monitoring so that the management of the skyline restaurant operational goods procurement runs well and there is no loss for employees or hotels.
\end{abstract}

\section{Keywords: Management, Procurement of goods, Restaurant}

\section{PENDAHULUAN}

Perkembangan industri pariwisata tidak lepas dari beberapa hal pendukungnya, antara lain akomodasi, makanan dan minuman, serta objek wisata. Salah satu industri pariwisata yang berperan adalah hotel. Industri jasa perhotelan merupakan salah satu bisnis industri pariwisata yang sangat komplek dengan bermacam ragam variasi disiplin ilmu dan dinamika lingkungan pekerjaannya.
Hotel merupakan sarana akomodasi atau tempat tinggal sementara serta tempat makan dan minum. Menurut Peraturan Menteri Pariwisata dan Ekonomi Kreatif Republik Indonesia Nomor 2 Tahun 2014 Pasal 1, "Hotel adalah penyedia akomodasi berupa kamar-kamar didalam suatu bangunan yang dapat dilengkapi dengan jasa pelayanan makan dan minum, kegiatan hiburan dan fasiltas lainnya secara harian dengan memperoleh keuntungan”. 
Industri jasa perhotelan merupakan salah satu bisnis industri pariwisata yang sangat komplek dengan bermacam ragam variasi disiplin ilmu dan dinamika lingkungan pekerjaannya. Salah satu industri jasa perhotelan yang ada di Kota Padang adalah Ibis Hotel Padang. Ibis Hotel ini merupakan salah satu hotel bintang tiga $(* * *)$ yang terletak di Jalan Taman Siswa Nomor 1 A Padang yang berada tepat di tengah kota. Ibis Hotel terdiri dari 11 lantai dengan 168 kamar yaitu lantai 1 - 10 memiliki tipe Superior dan Deluxe dengan pemandangan pantai dan gunung, juga Business Suite. Sedangkan lantai 11 terdapat ikon dari Ibis Hotel Padang yakni Skyline Restaurant.

Skyline Restaurant merupakan all day dining restaurant/ main dining restaurant di Ibis Hotel Padang. Skyline restaurant ini terletak diatap hotel (rooftop). Skyline restaurant memiliki suasana dan dua pemandangan yang indah. Disebelah kiri terdapat view pegunungan, dan disebelah kanan terdapat view pantai. Operasional Skyline restaurant yaitu 24 hours.

Berdasarkan observasi pada tanggal 20 Mei 2018 di Ibis Hotel Padang ini memiliki berbagai permasalahan dalam pengadaan barangnya. Salah satunya adalah proses dalam pembelian barang. Menurut Mann (2013) menyatakan bahwa, "Proses pembelian harus terdokumentasi dengan baik. Dokumen purchase order sesuai dengan kebutuhan dan ukuran pembelian. Tugas bagian pembelian harus dipisahkan dari fungsi fungsi lain".

Berdasarkan wawancara penulis dengan seorang staff dibagian purchasing department, masalah yang lebih penting dalam pengadaan barang ini adalah pengelolaan yang terlihat kurang teliti dan terlalu terburu - buru sehingga proses dalam setiap langkah pengadaan barang ini memiliki banyak masalah dan hambatan. Menurut Terry (2009 : 9), "Pengelolaan sama dengan manajemen sehingga pengelolaan dipahami sebagai suatu proses membeda-bedakan atas perencanaan, pengorganisasian, penggerakan, dan pengawasan dengan memanfaatkan baik ilmu maupun seni agar menyelesaikan tujuan yang telah ditetapkan sebelumnya".

Berdasarkan observasi dan wawancara di atas, berbagai masalah yang terjadi dalam pengadaan barang operasional di Skyline restaurant dapat diuraikan sebagai berikut:

1. Terkadang user tidak melakukan pemeriksaan langsung terhadap barang yang sudah datang pada saat diterima oleh receiving.

2. User sering melakukan kesalahan dalam memasukkan nama/ jenis barang disistem.

3. Kurangnya penjelasan/ kesalah pahaman dalam menjelaskan secara rinci jenis barang yang akan dibutuhkan.

4. Sering terjadinya pemesanan minuman kaleng/ botol secara berlebih. 
5. Adanya complaint tamu pada saat event.

Pada dunia perhotelan, bagian pengadaan barang merupakan bagian yang cukup penting dalam pelaksanaan proses dan prosedur pembelian. Bagian ini sering disebut dengan istilah "Purchasing". Seluruh rangkaian di hotel berawal dari proses purchasing karena bagian ini bertugas dalam menyediakan kebutuhan barang bagi semua department yang salah satunya yaitu dibagian restaurant. Berdasarkan permasalahan permasalahan yang telah dijelaskan, maka penulis tertarik untuk melakukan penelitian mengenai "Pengelolaan Pengadaan Barang Operasional Restoran Skyline di Hotel Ibis Padang".

\section{METODE PENELITIAN}

Dalam penelitian ini, jenis penelitian yang digunakan adalah penelitian deskriptif kualitatif. Metode yang digunakan dalam pengumpulan data adalah metode survey. Kriteria yang akan dijadikan informan adalah, Purchasing Department Ibis Hotel Padang, dan $F \& B$ Department Ibis Hotel Padang dengan teknik pengambilan sampel menggunakan purposive sampling.

Data dalam penelitian ini terdiri atas data primer dan data sekunder. Data primer diperoleh langsung dari responden dengan cara melakukan wawancara, observasi, dan dokumentasi. Sedangkan data sekunder diperoleh secara tidak langsung yaitu melalui perantara tentang gambaran umum pengelolaan pengadaan barang operasional restoran Skyline di Ibis Hotel Padang. Dalam penelitian ini menggunakan teknik analisis data model interaktif dari Miles dan Huberman dalam Sugiyono (2009 : 246), “Teknik pengumpulan analisis data kualitatif yang meliputi tiga alur kegiatan yakni reduksi data, penyajian data, dan pengambilan kesimpulan".

\section{HASIL PENELITIAN DAN PEMBAHASAN}

\section{Temuan Umum}

Hotel Ibis Padang memiliki 168 kamar berdesain modern minimalis, 3 ruang rapat canggih, kolam renang, pusat kebugaran, spa, bar, dan restoran di lantai atas dengan pemandangan laut dan pegunungan menakjubkan.

\section{Temuan Khusus}

\section{a. Permintaan Pembelian}

1) Perencanaan

Perencanaan permintaan pembelian dimulai dari user membuat PR sesuai dengan barang yang dibutuhkan. Dalam permintaan pembelian terdapat beberapa hambatan, salah satu diantaranya yaitu ketika user salah dalam memasukkan nama barang sehingga barang yang diorder pun salah.

2) Pengorganisasian

Yang terlibat dalam permintaan pembelian yaitu user, kemudian diproses oleh purchasing. Pembagian daftar 


kerja dalam mengelola
permintaan
berdasarkan penginputan PR
yang dilakukan oleh user.

3) Pengarahan

Pengarahan dalam permintaan pembelian dilakukan secara langsung oleh user kepada purchasing mengenai permintaan pembelian.

4) Pengawasan

Yang diutamakan dalam pengawasan permintaan barang yaitu memperhatikan mana barang yang termasuk kedalam barang urgent dan bukan.

b. Pemilihan Pemasok

1) Perencanaan

Dalam pemilihan pemasok ini perlu memperhatikan antara harga dan kualitas barang calon A dan B, serta memperhatikan jarak tempuh antara vendor dan hotel.

2) Pengorganisasian

Tidak ada struktur organisasi dalam pemilihan pemasok. Pemilihan pemasok ini seluruhnya diserahkan kepada purchasing dengan syarat yang ditetapkan oleh hotel.

3) Pengarahan

Pihak purchasing mengarahkan vendor untuk menyediakan barang yang sesuai dengan standar hotel yang ditetapkan.

\section{4) Pengawasan}

Dalam mengawasi pemilihan pemasok yaitu dengan cara membandingkan antara sampel yang diberikan dengan barang yang akan dipesan. Jika barang yg dipesan nantinya tidak sesuai dengan sampel yg pernah diberikan, maka purchasing tidak akan menuruskan vendor tersebut sebagai vendor di hotel ibis lagi.

c. Order Pembelian

1) Perencanaan

Perencanaan dalam order pembelian yaitu dengan memperhatikan kriteria barang yang dibutuhkan oleh user dengan barang disediakan oleh vendor.

2) Pengorganisasian

Pengkoordinasian order pembelian barang dimulai dari user membuat PR kemudian diproses oleh purchasing menjadi PO atau Market List dan mengorder barang ke vendor.

3) Pengarahan

Jika terjadi kendala dalam order pembelian yaitu dengan cara purchasing menelpon langsung kepada vendor mengenai spesifikasi barang yang diminta terutama pada saat sistem error.

4) Pengawasan

Purchasing harus lebih teliti dengan cara memastikan barang 
yang akan diorder tepat sasaran kepada vendor yang dituju. Jika barang yg dipesan nantinya tidak sesuai dengan sampel yg pernah diberikan, maka purchasing tidak akan menuruskan vendor tersebut sebagai vendor di hotel ibis lagi.

d. Penerimaan Barang

1) Perencanaan

Yang terlibat dalam merencanakan penerimaan barang adalah receiving dan user.

2) Pengorganisasian

Tugas dan tanggung jawab dalam penerimaan barang ini sepenuhnya diberikan kepada receiving yang memang sudah menjadi tugasnya.

3) Pengarahan

Purchasing mengarahkan user untuk ikut dalam penerimaan barang agar barang yang dikirim vendor yang tidak sesuai dan dapat langsung dikembalikan kepada vendor.

4) Pengawasan

Receiving perlu mengawasi kualitas barang yang diterima sesuai dengan yang dipesan dan memastikan tidak ada barang yang rusak ketika barang tersebut tiba di hotel.

e. Pencatatan Transaksi Pembelian

1) Perencanaan

Pencatatan transaksi pembelian dimulai dari vendor memberikan faktur kepada purchasing, lalu purchasing memberikan bukti tanda terima faktur yang dilengkapi dengan tanda tangan dan stempel hotel kepada vendor.

2) Pengorganisasian

Pengorganisasian pencatatan transaksi pembelian yaitu dengan pembagian tugas dan tanggung jawab antara receiving yang mengecek faktur pada saat penerimaan barang, dan purchasing yang memberikan surat tanda terima faktur kepada user setelah pengecekan antara faktur dan PO.

3) Pengarahan

Tidak ada aturan dalam pembuatan pencatatan transaksi pembelian.

4) Pengawasan

Mengecek kembali harga dan barang yang tertera pada faktur dengan harga barang yang pernah disetujui sebelum pembelian barang berlangsung.

\section{Pembahasan}

a. Perencanaan

Berdasarkan hasil reduksi data yang peneliti lakukan dengan metode wawancara, observasi dan dokumentasi, perencanaan tersebut dapat diuraikan sebagai berikut:

1) Dalam permintaan pembelian terdapat beberapa hambatan, salah satu diantaranya yaitu ketika user salah dalam 
memasukkan nama barang sehingga barang yang diorder pun salah.

2) Pemilihan pemasok ini perlu merencanakan perbandingan antara harga dan kualitas barang calon A dan B, serta memperhatikan jarak tempuh antara vendor dan hotel.

3) Perencanaan dalam order pembelian yaitu dengan memperhatikan kriteria barang yang dibutuhkan oleh user dengan barang disediakan oleh vendor.

4) Dalam merencanakan penerimaan barang perlu melibatkan beberapa orang, mereka adalah receiving dan user.

5) Pencatatan transaksi pembelian dimulai dari merenanakan vendor memberikan faktur kepada purchasing, lalu purchasing memberikan bukti tanda terima faktur yang sudah dilengkapi dengan tanda tangan dan stempel hotel kepada vendor.

Hal ini sesuai dengan teori yang dikemukakan oleh Siagan (2008 : 29), "Perencanaan merupakan keseluruhan proses pemikiran dan penentuan secara matang daripada hal-hal yang akan dikerjakan dimasa yang akan datang dalam rangka pencapaian yang sudah ditentukan". Menurut David (2011),
"Perencanaan adalah proses dimana seseorang menentukan apakah ia akan menyelesaikan tugas dengan cara yang berbeda dari cara yang paling efektif untuk mencapai tujuan yang diinginkan dan mempersiapkan untuk mengatasi kesulitan tak terdugadengan sumber daya yang memadai”.

b. Pengorganisasian

Berdasarkan hasil reduksi data yang peneliti lakukan dengan menggunakan metode wawancara, observasi, dan dokumentasi tentang pengorganisasian berdasarkan permintaan pembelian hingga pencatatan transaksi pembelian diuraikan sebagai berikut:

1) Pembagian daftar kerja dalam mengelola permintaan pembelian berdasarkan penginputan PR yang dilakukan oleh user yang kemudian diproses oleh purhasing menjadi PO atau Market List.

2) Tidak ada struktur organisasi dalam pemilihan pemasok.

3) Pengkoordinasian order pembelian barang dimulai dari user membuat PR kemudian diproses oleh purchasing menjadi PO atau Market List dan mengorder barang ke vendor.

4) Tugas dan tanggung jawab dalam penerimaan barang ini sepenuhnya diberikan kepada receiving. 
5) Pengorganisasian pencatatan transaksi pembelian yaitu dengan pembagian tugas dan tanggung jawab antara receiving yang mengecek faktur pada saat penerimaan barang, dan purchasing yang memberikan surat tanda terima faktur kepada user setelah pengecekan antara faktur dan $\mathrm{PO}$.

Hal ini sesuai dengan teori yang dikemukakan oleh Allen dalam Sukarna (2011 : 38), "Pengorganisasian sebagai proses penentuan dan pengelompokkan pekerjaan yang akan dilakukan, menetapkan dan melimpahkan tanggung jawab dan wewenang, serta mewujudkan hubungan tanggung jawab dengan maksud untuk memungkinkan orang-orang bekerja sama secara efektif dalam mencapai tujuan". Menurut Robbins dan Coulter (2010 : 239), "Pengorganisasian adalah menyusun dan menstruktur pekerjaan untuk mencapai sasaran organisasi".

c. Pengarahan

Berdasarkan hasil reduksi data yang peneliti lakukan dengan menggunakan metode wawancara, observasi, dan dokumentasi dari beberapa indikator yaitu permintaan pembelian hingga pencatatan transaksi pembelian, dalam bagian pengarahannya dijelaskan sebagai berikut:
1) Pengarahan dalam permintaan pembelian dilakukan secara langsung oleh user kepada purchasing mengenai permintaan pembelian.

2) Pihak purchasing mengarahkan vendor untuk menyediakan barang yang sesuai dengan standar hotel yang ditetapkan.

3) Pengarahan jika terjadi kendala dalam order pembelian yaitu dengan cara purchasing menelpon langsung kepada vendor mengenai spesifikasi barang yang diminta terutama pada saat sistem error.

4) Pengarahan dalam order pembelian yaitu purchasing mengarahkan user untuk ikut dalam penerimaan barang agar menghindari masalah.

5) Tidak ada aturan dalam pembuatan pencatatan transaksi pembelian. Pencatatan transaksi pembelian hanya diurus oleh purchasing saja.

Hal ini sesuai dengan Herlambang (2013 : 103) yang menyatakan bahwa, "Pengarahan merupakan suatu proses pembimbingan, pemberian petunjuk, dan instruksi kepada bawahan agar mereka mampu bekerja sesuai dengan rencana yang telah ditetapkan. Pengarahan juga berarti memberikan petunjuk kepada bawahan tentang apa yang harus mereka kerjakan. Pengarahan 
mencakup berbagai proses kegiatan, pedoman dalam buku panduan yang telah ditentukan oleh suatu perusahaan". Menurut Nitisusastro (2012 : 165), "Pengarahan merupakan proses mengarahkan atau memberikan pengarahan kepada staff atau karyawan agar melaksanakan tugasnya sesuai dengan rencana untuk mencapai suatu tujuan".

d. Pengawasan

Berdasarkan hasil reduksi data yang peneliti lakukan dengan menggunakan metode wawancara, observasi, dan dokumentasi tentang pengelolaan pengadaan barang opersaional restoran skyline, meliputi permintaan barang hingga pencatatan transaksi pembelian perlu adanya pengawasan. Berikut hasil dari penelitian beserta pembahasan dari peneliti adalah:

1) Pengawasan permintaan barang yaitu memperhatikan mana barang yang termasuk kedalam barang urgent dan bukan.

2) Mengawasi pemilihan pemasok yaitu dengan cara membandingkan antara sampel yang diberikan dengan barang yang akan dipesan.

3) Purchasing harus lebih teliti dalam hal mengawasi dengan cara memastikan barang yang akan diorder tepat sasaran kepada vendor yang dituju.
4) Receiving perlu mengawasi kualitas barang yang diterima sesuai dengan yang dipesan dan memastikan tidak ada barang yang rusak ketika barang tersebut tiba di hotel.

5) Pengawasan dalam pencatatan transaksi pembelian yaitu dengan mengecek kembali harga dan barang yang tertera pada faktur dengan harga barang yang pernah disetujui.

Hal ini sesuai Menurut Herlambang (2013 : 141), "Pengawasan merupakan proses unutuk menjamin bahwa tujuantujuan organisasi dan manajemen dapat tercapai. Proses ini berkaitan dengan cara-cara membuat kegiatan-kegiatan sesuai yang direncanakan". Sukarna (2011 : 112), diantaranya sebagai berikut:

1) "Untuk mengetahui jalannya pekerjaan apakah lancar atau tidak.

2) Untuk memperbaiki kesalahankesalahan yamg dibuat oleh pegawai dan mengusahakan pencegahan agar tidak terulang kembali kesalahan yang sama atau timbulnya kesalahankesalahan yang baru.

3) Untuk mengetahui apakah penggunaan budget yang telah ditetapkan dalam planning terarah kepada sasarannya dan sesuai dengan yang telah ditentukan. 
4) Untuk mengetahui apakah pelaksanaan biaya sesuai dengan program seperti yang telah ditentukan dalam planning atau tidak.

5) Untuk mengetahui hasil pekerjaan dibandingkan dengan yang telah ditetapkan dalam rencana dan sebagai tambahan".

\section{KESIMPULAN DAN SARAN}

\section{Kesimpulan}

Berdasarkan hasil penelitian
yang diperoleh dari wawancara,
observasi dan dokumentasi, maka
dapat diambil kesimpulan bahwa
pengelolaan pengadaan barang
operasional restoran skyline di hotel
Ibis Padang, sebagai berikut:

a. Permintaan pembelian berkaitan dengan perencanaan, pengorganisasian, pengarahan, dan pengawasan oleh pengelola pengadaan barang yaitu agar permintaan pembelian dapat diproses sesuai alur kerjanya dan tidak memakan waktu yang cukup lama, juga tentunya agar kita mendapatkan harga yang sesuai, kualitas terbaik, dan lokasi pengiriman yang tepat.

b. Pemilihan pemasok perlu diperhatikan dalam hal perencanaan, pengorganisasian, pengarahan, dan pengawasan karena apabila pemasok tidak sesuai dengan standar yang hotel tetapkan, maka barang yang miliki pemasok juga tidak akan sesuai dengan kriteria yang dibutuhkan oleh hotel.

c. Order pembelian barang dimulai dari penyusunan perencanaan, pengorganisasian, pengarahan, dan pengawasan agar dapat memenuhi proses pembelian barang. Perlu adanya syarat dan ketentuan dalam order pembelian barang diantaranya adalah harga, kualitas, dan tipe barang yang akan diorder.

d. Dalam hal penerimaan barang banyak hal yang perlu diperhatikan, diantaranya adalah perencanaan, pengorganisasian, pengarahan, dan pengawasan agar barang yang diterima tidak ada masalah dalam bentuk apapun. Hal ini penting agar mutu barang tetap terjaga jangan sampai terjadi kerusakan pada saat penerimaan barang, karena pada saat kita menerima barang, pada saat itu juga kita berhutang kepada vendor.

e. Pencatatan transaksi pembelian merupakan hal yang terpenting dalam pengelolaan pengadaan barang yaitu memperhatikan perencanaan, pengorganisasian, pengarahan, dan pengawasan. Keempat hal tersebut sangat penting karena sebagai referensi pada saat pembayaran hutang dilakukan kepada vendor dan penentuan jatuh tempo pembayaran yang telah disepakati antara vendor dan pihak accounting. 


\section{Saran}

Bagi Manajemen Hotel Ibis Padang serta karyawan dibagian purchasing dan restoran skyline agar lebih memperhatikan jalannya operasinal hotel, khususnya dalam mengelola pengadaan barang operasional restoran skyline dan pihak yang terkait dalam mengelola pengadaan barang diharapkan lebih berhati-hati atau lebih memperhatikan beberapa hal penting agar tidak terjadi kerugian bagi hotel bahkan karyawan yang bertugas dalam mengelola pengadaan barang.

Bagi mahasiswa/i prodi Manajemen perhotelan untuk mempraktekkan ilmu yang telah dipelajari pada saat mata kuliah Pengembangan Sumber Daya Manusia (PSDM), Akuntansi, Pengantar Perhotelan, dan sebagainya sebagai bahan pegangan sebelum memasuki dunia industri dan dapat mempermudah dalam mengerjakan skripsi.

Penelitian ini juga diharapkan dapat memberikan tambahan materi mengenai pengadaan barang operasional restoran. Selanjutnya bagi peneliti berikutnya bisa dijadikan sebagai referensi dalam penulisan karya ilmiah ataupun dapat melakukan penelitian yang berkaitan dengan pengelolaan pengadaan barang dibagian department lainnya.

\section{DAFTAR PUSTAKA}

David, Fred. 2011. Strategic Management, Buku 1, Edisi 15. Jakarta

Herlambang, Susatyo. 2013. Pengantar manajemen (Cara Mudah Memahami Ilmu Manajemen). Gosyen Publishing. Yogyakarta.

Nitisusastro, Mulyadi. 2012. Perilaku Konsumen Dalam Perspektif Kewirausahaan. Bandung: Alfabeta.

Robbins, Stephen P dan Coulter, Mary. 2010. Manajemen, Edisi Kesepuluh. Jakarta: Erlangga.

Siagan, Sondang P. 2008. Manajemen Sumber Daya Manusia, Edisi Pertama. Jakarta: Binapura Aksara.

Sukarna. 2011. Dasar-Dasar Manajemen. CV Mandar Maju. Bandung. 